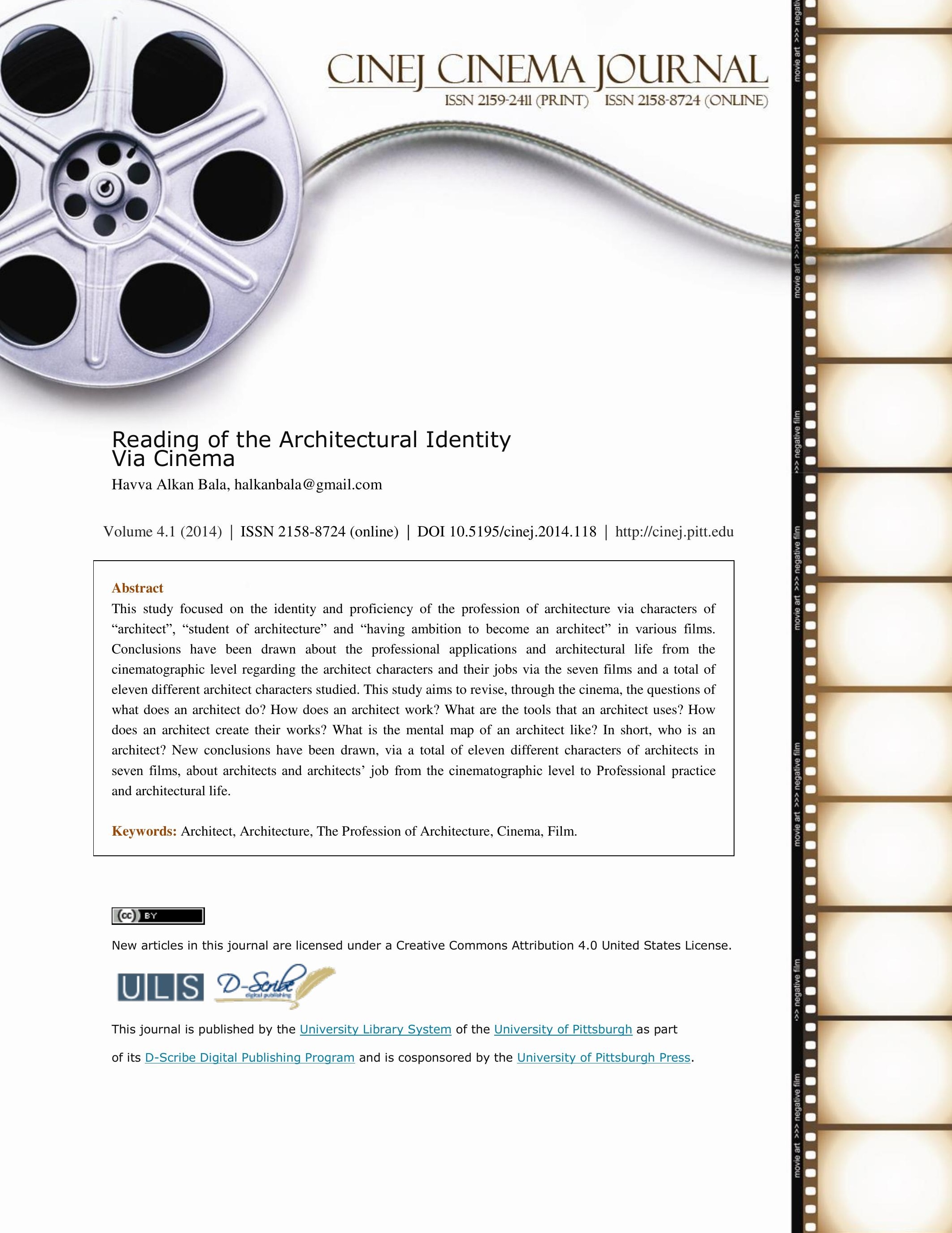





\section{Reading Of the Architectural Identity Via Cinema}

Havva Alkan Bala

\section{INTRODUCTION}

Interactions between the cinema and architecture have been investigated in the relevant literature many times from different perspectives because these two disciplines have taught each other new ways of seeing and producing. The interaction between the cinema and architecture can be regarded as a point of intersection where films play a role in the formation of architectural circles and in the inclusion of these circles in people's lives. This study is interested in the way the profession of architecture is defined in the cinema, not in the space in the cinema. The text aims to revise, through the cinema, the questions of what does an architect do? How does an architect work? What are the tools that an architect uses? How does an architect create their works? What is the mental map of an architect like? In short, who is an architect? The reason why this article was penned is that today the profession of architecture as a concept is gradually losing ground in professional applications and social status. Reading the identity and proficiency of an architect via films rather than practical life is perhaps a bolt hole for architects as the art of cinema is in essence.

The identity and proficiency of the architecture has been defined since Ancient times. The status of the architecture was defined clearly through social codes in the Greek and Roman ages. In his work in 25 B.C, De Architectura, which is considered one of the masterpieces of Architecture literature, Vitruvius began defining the architect and architecture on the basis of education. According to Vitruvius (1993), the architect is a person who is equipped with 
different disciplines, possesses natural talents, is trainable at the same time, can write well, well-versed in geometry, history, philosophy and philosophers, appreciates music, has a certain knowledge of medicine, can grasp the notion of law and is even familiar to astrology and astronomy. Vitrivius provides a detailed description of the job of an architect in those times. In Doğan Hasol's Encyclopedic Dictionary, too, it is emphasized, with reference to Vitrivius, that an architect needs to have an overall knowledge of structure, heating, ventilation, lighting and plumbing. While definitions of architecture covers technical drawings, plan plane, structure, building components, material, technology, construction activity and the production process clearly, elements such as life, people, ideology, intuition, pleasure and humanism have a covert reference in it.

According to Tanyeli (2001), there are three types of relationship-interaction between cinema and architecture.

1-"unbuilt" and virtual architectural area that is not being used in reality

2-cinema reproducing the "real" architectural spaces in its own virtual universe 3-cinema taking "the architects as a personality and his/her architectural activities" (Gençosmanoğlu, 2012). This study makes mention of films as fourth group that deals with areas of work of the profession of architecture.

This study aimed to define the identity and proficiency of the profession of architecture via characters of "architect", "student of architecture" and "having ambition to become an architect" in various films. The selected films do not focus on the director, date of shooting the film, the technique used in filming and the context where the film takes place; instead, they 
focus on the architect that was included in the screenplay. Undoubtedly, while these lines are being written and while they are being read by you now, the question of "Why was the film " $\mathrm{x}$ ", in which the architect character is more dominant, not included in this article whereas even the film "y" was analyzed?" is quite meaningful and appropriate. In fact, perhaps the screenplay of a new film is being written at the moment, a film is being shot at a setting, or being premiered. However, when the films analyzed in this article are looked at as a context, it is seen that the holistic potentials of the films are important rather than their individual existence. In other words, what matter is that films constitute a cinematographic level reflecting the architect within a system rather than which films were included in the article and how they were analyzed (Table 1). The lead characters or side characters in the films analyzed in this study are architects and the focus here is on the theoretical and practical functioning of the profession of architecture. The films emphasize sometimes the architect's identity regarding their profession and sometimes their emotions. As is seen in the case of Truman Show, we can feel the creative, supervisory and founding qualities of architecture in the background.

Table1. List of films

\begin{tabular}{|c|c|c|}
\hline The Films & $\begin{array}{l}\text { Production } \\
\text { Director } \\
\text { Cast } \\
\text { The architect character in the film and } \\
\text { the architect's job definition }\end{array}$ & The Plot of the Film \\
\hline $\begin{array}{l}\text { THE } \\
\text { FOUNTAINED }\end{array}$ & $\begin{array}{l}1949 \\
\text { King Vidor } \\
\text { Gary Cooper, }\end{array}$ & $\begin{array}{l}\text { The film was adapted from a novel by Ayn Rand bearing } \\
\text { the same title. Howard Roark, a talented designer, is } \\
\text { dismissed from the architecture school because he refuses } \\
\text { traditional drawings. Roark intends to go to and work for } \\
\text { architect Henry Cameron, who has been excluded from the }\end{array}$ \\
\hline
\end{tabular}




\begin{tabular}{|c|c|c|}
\hline $\begin{array}{l}\text { PATRICIAY) } \\
\text { IHIUNIALY }\end{array}$ & $\begin{array}{l}\text { Patricia Neal, Raymond Massey, } \\
\text { Kent Smith, } \\
\text { Robert Douglas } \\
\text { Of the two architect characters, Howard } \\
\text { Roark (Gary Cooper) is a talented } \\
\text { architect who never makes concessions } \\
\text { on his principles, } \\
\text { whereas Peter Keating (Kent Smith) is } \\
\text { an architect who lacks talent but has } \\
\text { made a career and earned a fortune by } \\
\text { catering to the requirements of the } \\
\text { sector and making concessions on } \\
\text { design. The architects in the film make } \\
\text { designs, implement projects and } \\
\text { sometimes submit project proposals for } \\
\text { competitions. }\end{array}$ & $\begin{array}{l}\text { architectural circles due to his modern style and is not in } \\
\text { much favor. When Henry Cameron goes bankrupt, Roark } \\
\text { opens a small office for himself. He is in constant conflict } \\
\text { with his employers as he does not make concessions on } \\
\text { unique and functional architecture. Roark has accepted the } \\
\text { Cortland residences project, which is a large scale project, } \\
\text { on condition that no alterations will be made to it. However, } \\
\text { when he sees the alterations made in practice, he dynamites } \\
\text { his own project. He is found not guilt by the court as he has } \\
\text { made an impressive defense advocating the architect's } \\
\text { copyrights. Roak is broke but prefers closing down his } \\
\text { office and working in a quarry to making concessions on } \\
\text { architecture. The other architect character in the film, Peter } \\
\text { Keating, is Roak's classmate and exact opposite, who uses } \\
\text { architecture as a tool for earning money and fame, lacks } \\
\text { talent but is successful as he is ready to make concessions. }\end{array}$ \\
\hline INCEPTION & $\begin{array}{l}\text { The fact that Ariadne, a character in the } \\
\text { film Inception is a young woman with a } \\
\text { superior talent for design and at the } \\
\text { same a student of architecture gives a } \\
\text { conscious message, and performs } \\
\text { "mental architecture". }\end{array}$ & $\begin{array}{l}\text { Dom Cobb (Leonardo DiCaprio) is an ex-architect who, } \\
\text { during a dream when the mind is at its most indefensible, is } \\
\text { specialized in bringing out valuable secrets in the depths of } \\
\text { subconsciousness and stealing them. As a result of this, } \\
\text { Dom becomes an international spy and a fugitive. Dom's } \\
\text { ability to steal ideas has caused him to lose all that he loves } \\
\text { including his family and job. Dom is given a last job that } \\
\text { might help him get out of the situation he is in and give him } \\
\text { back his past life. Dom sets up a professional team with } \\
\text { special skills for this task. The job is not to steal the idea } \\
\text { but to infuse it. On the other hand, a gifted student of } \\
\text { architecture, Ariadne, undertakes the job of designing the } \\
\text { spaces of layers of dreams. Ariadne has accepted this } \\
\text { dangerous and illegal job because she has been unable to } \\
\text { resist the experience of "pure creativity". Ariadne is a } \\
\text { character who learns fast, and does not hesitate to take risks } \\
\text { in the name of creative experience. }\end{array}$ \\
\hline LAKE & 2006 & The film, which puts the classic movie theme "love born \\
\hline
\end{tabular}




\begin{tabular}{|c|c|c|}
\hline HOUSE & $\begin{array}{l}\text { Three architect characters } \\
\text { Alex Wyler is a free-spirited person } \\
\text { who can add love to architecture in his } \\
\text { thinking; his brother on the other hand, } \\
\text { thinks reasonably and reflects this in } \\
\text { his designs; his father Simon Wyler is a } \\
\text { man of principles who does not accept } \\
\text { any missing parts and deals with } \\
\text { architecture at all times. Alex continues } \\
\text { his architectural activities at the } \\
\text { construction site whereas Simon works } \\
\text { in his Office. Alex's brother, on the } \\
\text { other hand, is a student of architecture. }\end{array}$ & $\begin{array}{l}\text { out of correspondence" at the center of its story, begins } \\
\text { when doctor Kate Forster moves to Chicago and leaves a } \\
\text { letter for the next lodger in the mailbox of her beloved } \\
\text { lakeside house. This note tells him to love the house, take } \\
\text { good care of it and provides information about mysterious } \\
\text { paw prints on the door and her new mail address. The new } \\
\text { lodger of the house, Alex Wyler, is an architect who runs a } \\
\text { construction site nearby after disappointments in his career } \\
\text { despite his talent. Alex finds the house much neglected } \\
\text { unlike what Kate's note claims and there are no traces of } \\
\text { paw prints anywhere. The house has a special significance } \\
\text { for Alex. This building was designed in Alex's happier days } \\
\text { by his father, a famous architect, who sacrificed at the } \\
\text { expense of his professional success. Alex, who takes no } \\
\text { heed of Kate's note, begins to paint the fence around the } \\
\text { house one day and sees that a stray dog proceeds towards } \\
\text { the entrance of the house after stepping on wet paint and } \\
\text { leaves paw prints at the exact place Kate had mentioned. } \\
\text { Puzzled by this, Alex writes a letter to Kate: "I ask only out } \\
\text { of curiosity; what is the date there? } 14 \text { April } \\
2004 \text { ?"..."No", says Kate, Today is } 16 \text { April } 2006 \text {. The } \\
\text { same day, but two years later." While Kate and Alex } \\
\text { continue to correspond via the mailbox of the lakeside } \\
\text { house, they see impossibly that they live in two different } \\
\text { years. The couple, who has formed an unusual bond } \\
\text { between them through their correspondence, falls in love } \\
\text { with each other. }\end{array}$ \\
\hline $\begin{array}{l}\text { LIFE AS } \\
\text { HOUSE }\end{array}$ & $\begin{array}{l}\text { Kevin Kline, Jena Malone, } \\
\text { Kristin Scott Thomas, } \\
\text { Hayden Christensen }\end{array}$ & $\begin{array}{l}\text { Kevin Kline (George Monroe) is an architect who } \\
\text { experiences architecture via models and has not been able } \\
\text { to meet his expectations of life so far. Determined not to } \\
\text { perform architecture in accordance with the wishes of } \\
\text { others, George is dismissed from his workplace after he } \\
\text { learns about his fatal illness and upon learning that he will } \\
\text { not be allowed to take even one of the models he has made }\end{array}$ \\
\hline
\end{tabular}




\begin{tabular}{|c|c|c|}
\hline & $\begin{array}{l}\text { The chief character George Monroe is } \\
\text { specialized in architectural models in a } \\
\text { busy architectural company. }\end{array}$ & $\begin{array}{l}\text { with him, he destroys them. Then, he takes his with him and } \\
\text { the two go to the small cabin where he lives. And, he picks } \\
\text { up a sledgehammer and demolishes the cabin in which he } \\
\text { has bad memories. Soon, he becomes the center of attention } \\
\text { for his son, ex-wife and neighbors a new life begins as a } \\
\text { result of a huge cooperation. The house which he has } \\
\text { designed with his very hands is not a house alone; it is a } \\
\text { new life. }\end{array}$ \\
\hline $\begin{array}{l}\text { UN AMOUR } \\
\text { DE JEUNESSE }\end{array}$ & $\begin{array}{l}2011 \\
\text { Mia Hansen-Løve } \\
\text { Lola Créton Sebastian, Urzendowsky } \\
\text { Magne-Håvard Brekke } \\
\text { The internal dynamics of the } \\
\text { architecture education are seen in } \\
\text { detail. }\end{array}$ & $\begin{array}{l}\text { 15-year-old Camille is a serious young girl who believes in } \\
\text { logic. Her boyfriend Sullivan is full of life and wants to } \\
\text { discover the world. Though he is in love with her, Sullivan } \\
\text { leaves Camille' for his freedom and a tour to South } \\
\text { America. The young girl falls into such a depression as to } \\
\text { attempt suicide. She finds the way to holding onto life in } \\
\text { enrolling at the architecture school. The education she has } \\
\text { received at the architecture school totally changes her view } \\
\text { of life and relationships. The effects of her teacher and later } \\
\text { her husband, professor of architecture Caille Lorenz have a } \\
\text { special place in her life. }\end{array}$ \\
\hline 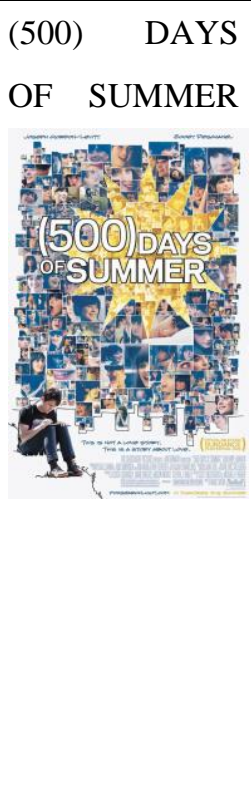 & $\begin{array}{l}\text { Tom has studied architecture, loves it at } \\
\text { heart but has opted for another kind of } \\
\text { design rather than architecture as he } \\
\text { lacks self-confidence. Via him, the } \\
\text { relationship between architecture and } \\
\text { the city is depicted through sketches. }\end{array}$ & $\begin{array}{l}\text { The film tells the 500-day-story story of Tom, a young man } \\
\text { who has studied architecture and makes a living working as } \\
\text { a writer in a greeting card company, and Summer, a young } \\
\text { woman not having faith in love who works as secretary to } \\
\text { the company. Not having a linear story, the film shows } \\
\text { scenes from the 500-day-stroy without sticking to a } \\
\text { chronological order. While the } 500 \text { days are told, a "passing } \\
\text { screen" shows which day is being shown before the scenes } \\
\text { begin and whether that day is a good one or a bad one can } \\
\text { be understood from the colors used. The director of the } \\
\text { film, Marc Webb usually directs viedo clips, and the effects } \\
\text { of his career as a video clip director are quite obvious in } \\
\text { this first long film of his. }\end{array}$ \\
\hline
\end{tabular}




\begin{tabular}{|c|c|c|}
\hline & $\begin{array}{l}\text { Peter Weir } \\
\text { Jim Carrey, } \\
\text { Paul Giamatti, } \\
\text { Laura Linney, } \\
\text { Ed Haris, } \\
\text { Natascha Mcelho, }\end{array}$ & $\begin{array}{l}\text { Christof, who is an architect in fact but works as a TV } \\
\text { producer, adopts Truman to satisfy the need for } \\
\text { "truthfulness" on the screen and makes him a star whose } \\
\text { life has been watched by millions since he was born. The } \\
\text { place where Truman lives is in fact a specially designed } \\
\text { film studio. Truman's parents, partner, colleagues and } \\
\text { neighbor are carefully chosen actors and actresses. } \\
\text { Everyone but Truman acts their roles. The story of a boat } \\
\text { trip at a young age where he lost his father and hence his } \\
\text { fear of water has been purposely coined to prevent him } \\
\text { from leaving the island. The errors the director has made } \\
\text { and his finding true love raises Truman's awareness. } \\
\text { Truman wants to escape and get in touch with reality and } \\
\text { therefore leaves the stage for freedom bowing to the } \\
\text { audiences, facing his biggest fears and risking death. }\end{array}$ \\
\hline
\end{tabular}

\section{THE ARCHITECTS AND ENDEAVORS OF ARCHITECTS FROM FILM FRAMES}

Conclusions have been drawn about the professional applications and architectural life from the cinematographic level regarding the architect characters and their jobs via the seven films and a total of eleven different architect characters studied. The sub-headings here have been determined on the basis of the internal dynamics of the films.

\subsection{How does an architect work?}

It is seen that the architects in the films usually express themselves through sketches and drawings in professional dimension. In The Fountainhead', Howard Roak is seen throughout the film with paper and pen in his hand making sketches and drawings at a white flat table. Although occasionally we see Roak as a businessman in a suit at stressful business meetings with employers, a bureaucrat defending himself at courtrooms making long defense 
speeches in the name of his profession, or as a worker with a tool he uses to bore stones and dressed in dungarees, the general image of him is one of an architect engaged in sketches and drawings. He prefers to make presentations to employers with elaborate and well-proportioned sketches on which he put his signature (Figure 1).

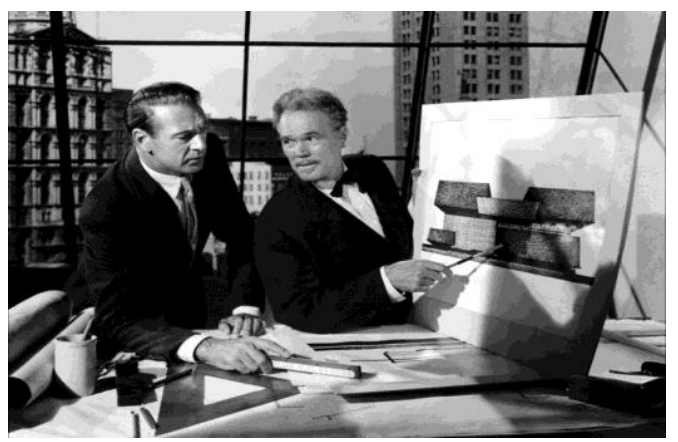

Figure 1. Howard Roak's project presentations in the film The Fountained The film also shows the latest forms of various buildings. Roak usually prepares his projects with presentations of sketches containing technical drawings consisting of plans, cross-sections and façades (Figure 2).

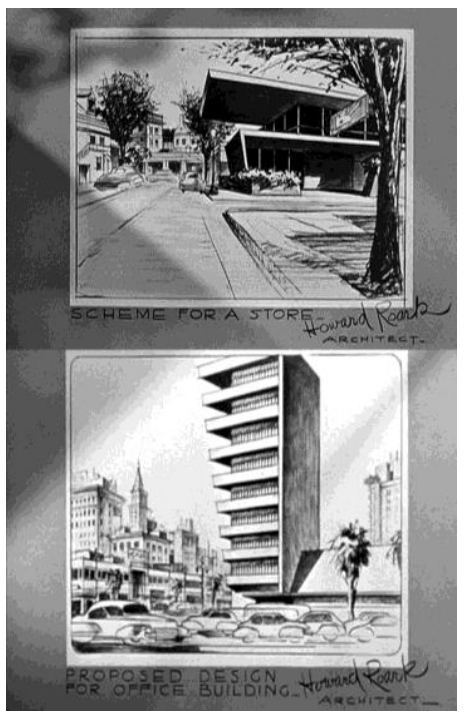

Figure 2. Howard Roak's signed sketch works in the The Fountained 
Likewise, in the film Lake House, architect Alex is depicted as working at a white, lighted, large and flat table making sketches, hands in paint, his back in pains due to long times spent at the table, trying to reflect his ideas on paper (Figure 3).

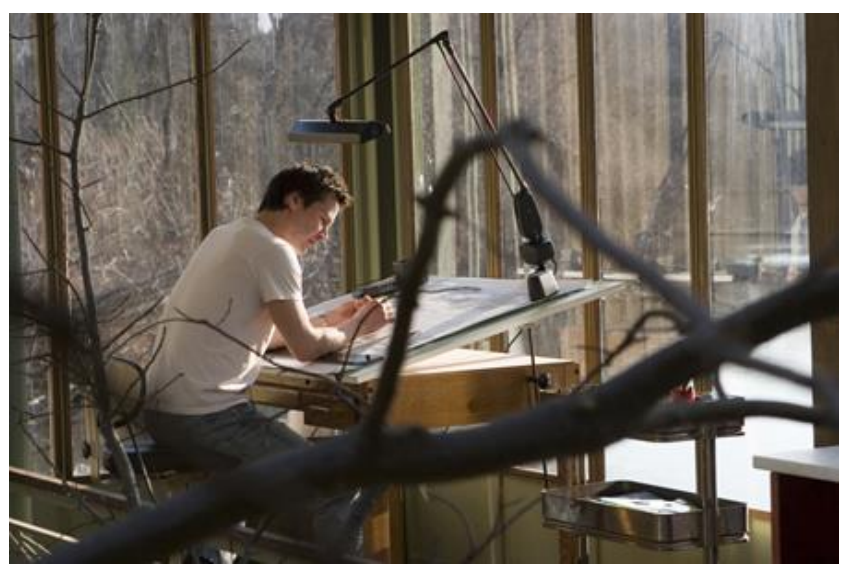

Figure 3. Architect Alex drawing at his table (Lake House)

The architect character in the film 500 Days of Summer is depicted as making drawings and sketches. In the film, in every scene connected with architecture, Tom helps us have an idea of his architectural visual thinking and drawing skills by drawing a silhouette of the city on Summer's arm as well as making sketches on paper. Another show of his sketching skill is portrayed when he draws a skyscraper he has designed on a giant blackboard in the bedroom. At the end of the Expectations - Reality scene, having realized that Summer has been engaged, Tom leaves the house in disappointment, and begins to walk but suddenly stops in the middle of the street and he and the street take the form of sketch drawing, being erased subsequently. In this scene, how Tom, who is a character not performing architecture though he loves it but defines himself with reference to buildings, feels non-existent upon learning that the woman he loves has been engaged to marry is expressed through the image of the city around him losing its existence by being erased. In other words, we see an architect who 
positions himself in front of a structure, sees and feels it, listens to its interaction with its environment, understand what it says from the way it stands and speaks through his drawings. Thinking through sketches, bringing sketches to life, and starting a communication via sketches is a way of existence for an architect (Figure 4).
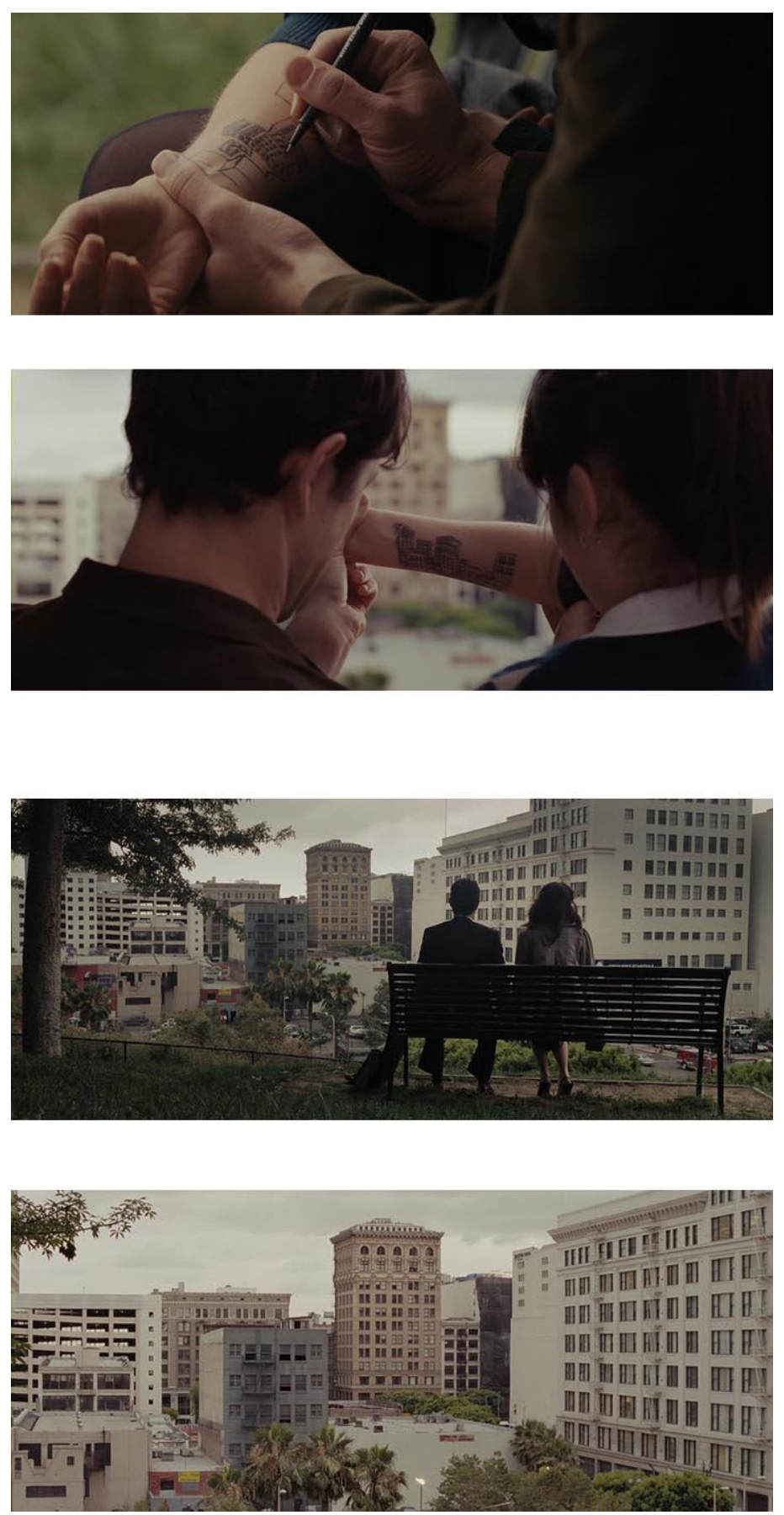
Figure 4. A sketch is way of thinking and communicating for an architect (500 Days of Summer).

In the film Life as A House, on the other hand, the model replaces the sketch in the expression of architecture. The model is an important architectural technique for expression enabling a perceptive ease. George Monroe, the chief character who undertakes the job of making models in an architecture firm, prefers to improve his talent in this field. For George, the architectural models he makes is a way of getting rid of the ordinary and worthless burdens imposed on him by life. Architectural models appear as a passion performed with patience. The process of how hand-made models have lost their appeal in the face of three-dimensional digital modeling is pointed out at the beginning of the film (Figure 5).
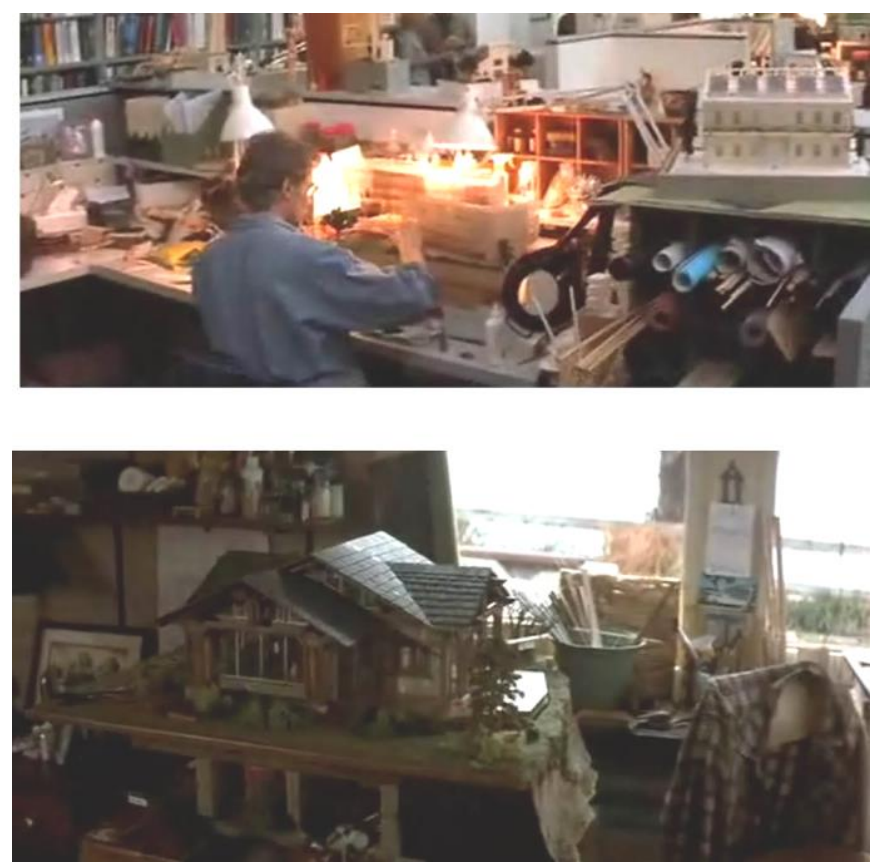

Figure 5. The model is one of the means of expression for architects (Life as a House) 
In a scene in the film The Fountainhead, we see Roak's proposed skyscraper model, which has been detailed quite professionally. The employers insist that forms taken from history be added to Roak's modern and unique skyscraper proposal and again additions are made on the model. It is unclear whether this detailed skyscraper model has been prepared by Roak or the employers (Figure 6).

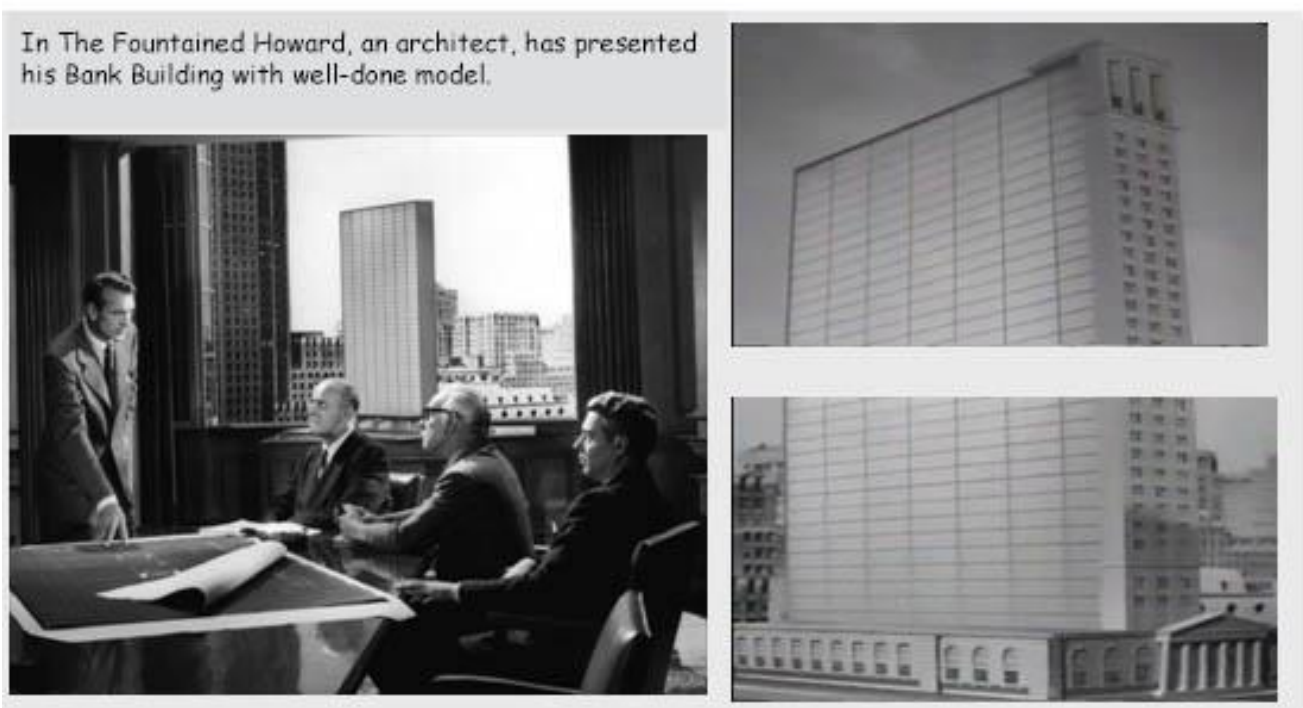

Figure 6. In the film The Fountainhead, architect Howard presents his project proposals on models

In the film Un Amaour de Jeunesse, a student of architecture, Camile works on a model when she tries to develop her design in her project. She uses the model by breaking, adding and removing (Figure 7) 

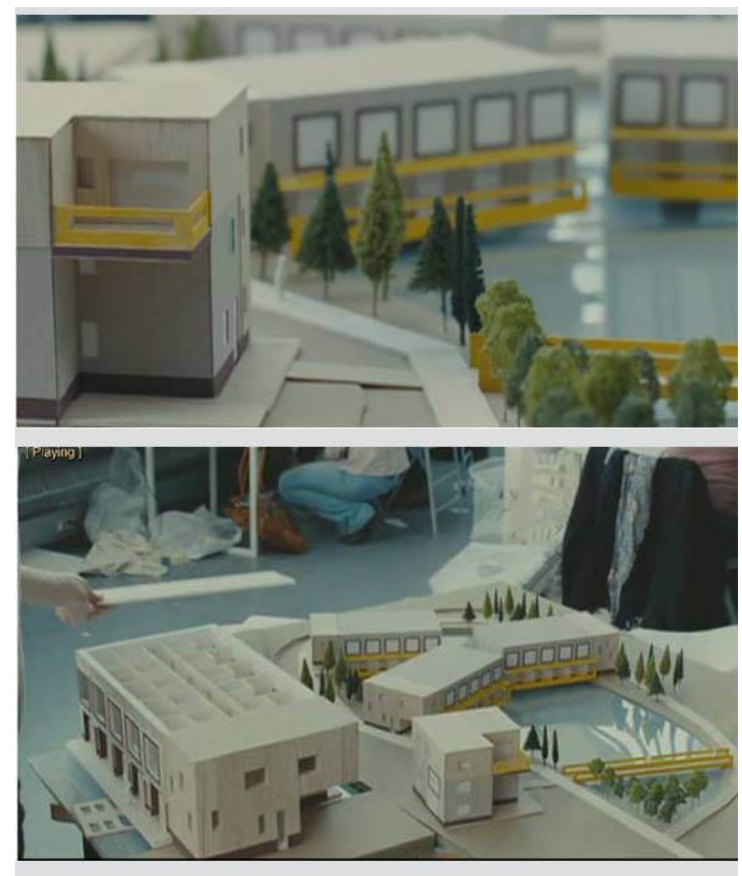

Figure 7. In the film Un Amaour de Jeunesse, students of architecture implement their projects via models

Apart from drawings, sketches and models, we see that in the films 500 Days of Summer and The Lake House, architects enjoy walking around the city to watch the buildings they like best, explore their details and making observations regarding the buildings in the city. In 500 Days of Summer, Tom sits at his "favorite spot" in Los Angeles, a bench, and watches the Continental Building for hours. He sits on the roof of a building and makes sketches of buildings in the sunlight, which changes throughout the day. In The Lake House, Alex likes, on a day when the lights are very clear, walking in the streets of the city and "touching" the details of the buildings. Observing the city they live from an archaeological perspective and thus feeding their visual memory is a method of working that architects often resort to. 
We also witness life at the construction site within the working conditions and methods of architects in the films. In some scenes from the film The Lake House, we see Alex's life at the construction site. The architect is defined as someone who undertakes the job of preparing the work schedule, coordination, material selection and task distribution and keeps the work going (Figure 8).
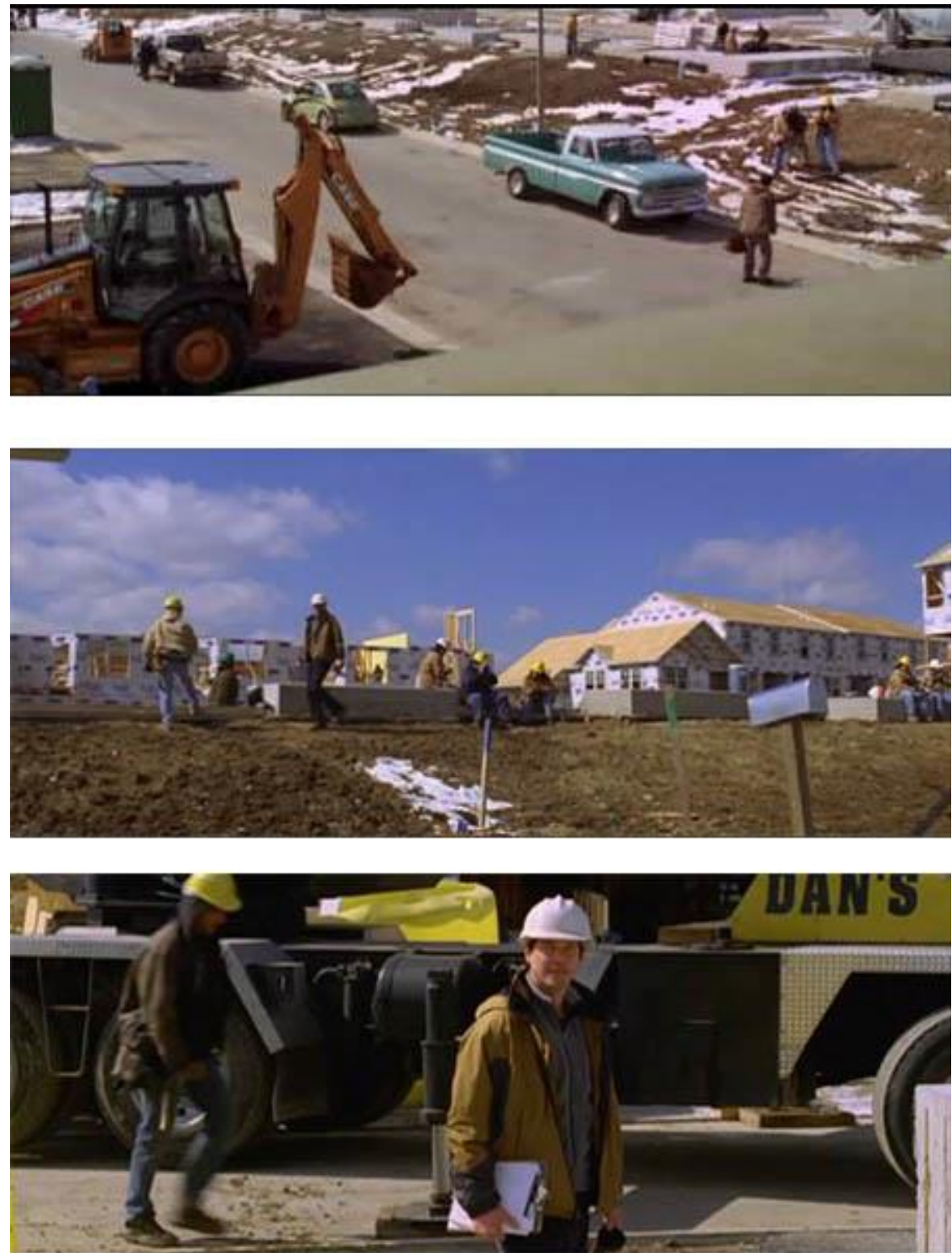

Figure 8. Architect at the Construction site (The Lake House) 
At the scene in the film The Fountainhead where Dominique goes to see Roark, life at the construction site is shown briefly. In the film Un Amaour de Jeunesse, the loves affair between Lorenz, who teaches at an architecture school, and his student Camille evolves into a business partnership. Camille and Lorenz begin to work together on a restoration project. The design of a detail which the architect has produced spontaneously by drawing on the wall using an object he has found on the ground to solve a detail at the construction site where restoration is being performed is impressive in that it shows the dynamism and liveliness of life at the construction site (Figure 9).
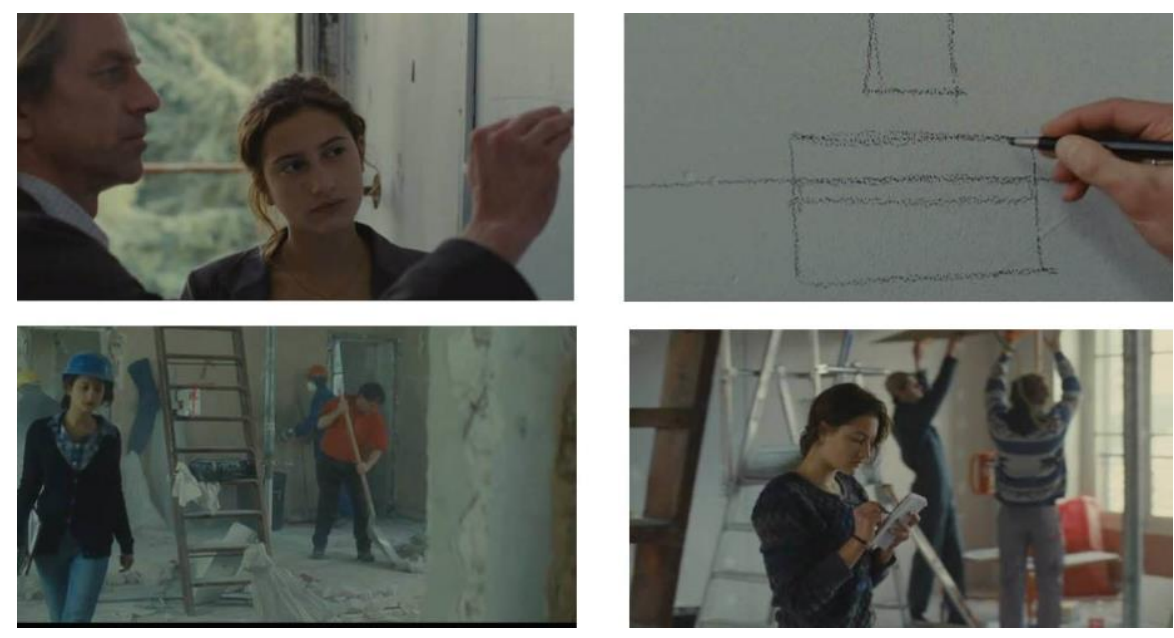

Figure 9. Design at the construction site (Un Amaour de Jeunesse)

Apart from the partially stereotyped lives of architects involving sketches, drawings, models, working at a table and at the construction site, we also see modern architectural working conditions and methods that have quite a predictive power in the films. In the film Inception, Ariadne provides inspiration for the world of architecture by making her designs in an environment quite different from that of the working conditions that architects often use. The young student of architecture describes her designs in her dreams. When a bridge is dreamed of, a physical bridge is created. She climbs endless stairs, which are a paradox in the 
physical world, and conducts experiments of design concerning what might happen if she furnishes the city with mirrors (the mirror command in CAD programs). Although she works in this manner in her dreams, in the physical world, she shares her dreams with others using models, sketches and models in three-dimensional computer programs (Figure 10).
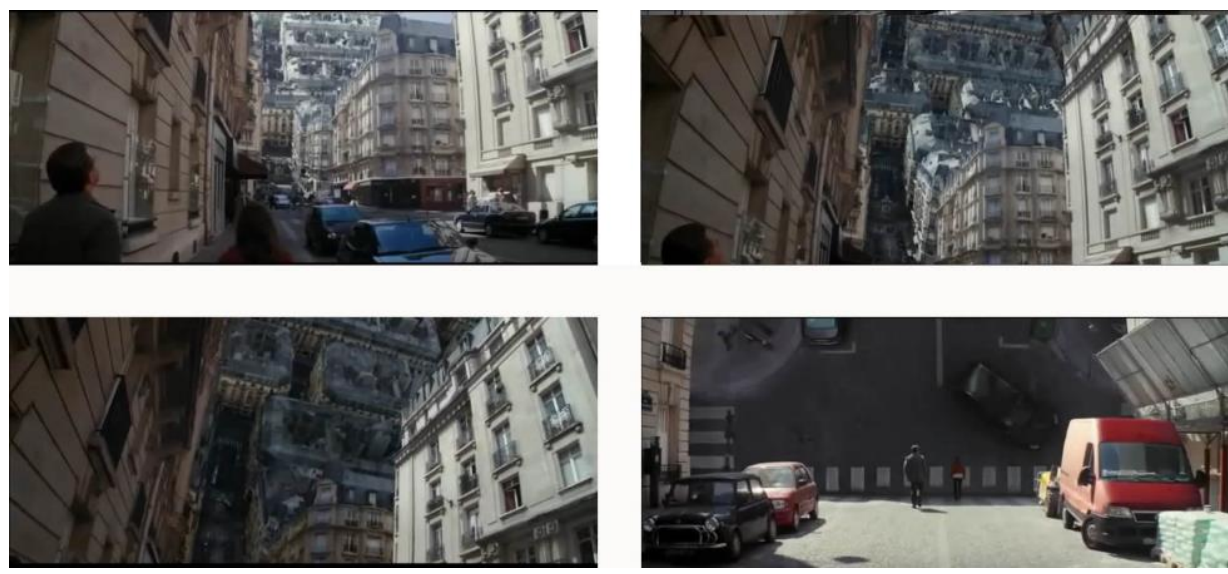

Figure 10. Inception and mental architecture

Truman Show is, just like Inception, a film that almost goes beyond the limits of the definition, endeavors and borders of architecture. The architect character in Truman Show is a film producer and director. Architect Christof has designed the island of Seahaven, which is a world within the world, as a film set under a dome for the project which began with idea of having people watch a person's life live from the beginning to the end. The island is a stage and everybody plays their part every day in a specific circle. Here, the architect defines himself like God (Figure11). He has rain fall whenever he wants, has the sun rise whenever he likes and organizes many natural phenomena like this. On this island, the architect is a designer of not only buildings and the shape of the island but at the same time lives. 

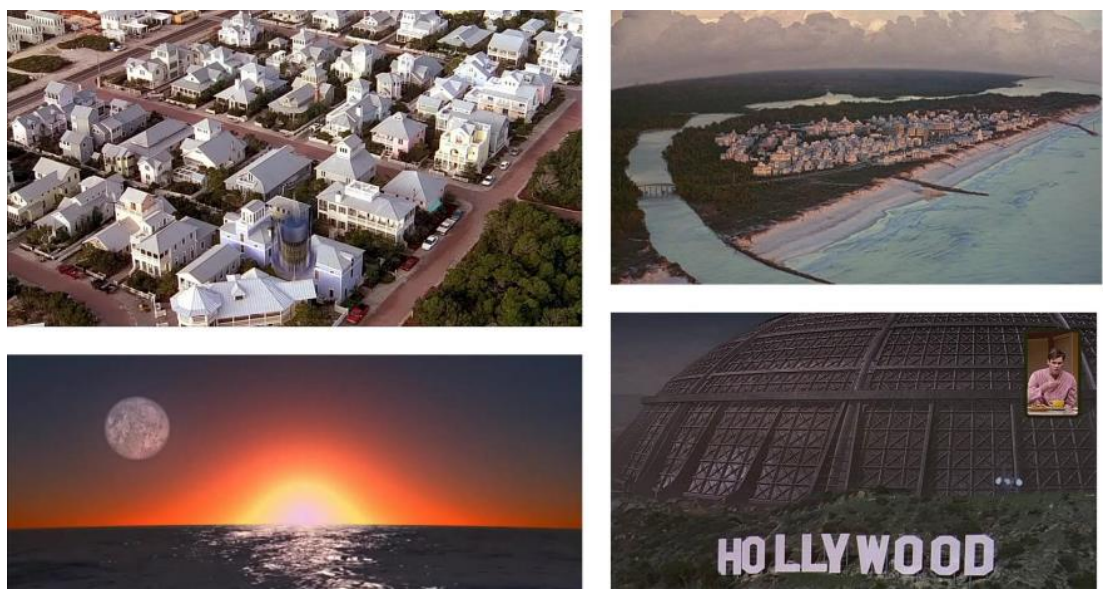

Figure 11. The architect as a designer of life and one that imitates the creator (Truman Show)

Though not as extreme as in Truman Show, we encounter this quality of architectural management and organization in the film The Lake House. The father, who is an architect, is one who manages and directs a work group involving his sons. In the same film, again, the quality of the architect as a manager is enhanced with the quality of writing. Simon Wyler, as an experienced architect, believes in the importance of passing on his experiences to the posterity. Therefore, the architect is also a person who writes books, and conveys his works, sketches, ideas and sources of inspiration to the future generations.

\subsection{The Architect-Employer Relationship}

It is possible to get an idea of how architects are given jobs and establish relationships with employers from the films. Our idealist architect in The Fountainhead, Howard Roak does not concede to the wishes of his clients who insist on making historic additions or deletions to his modern architectural work proposals and loses those jobs although he has not got a job contract for more than a year and is almost about to close his office for economic reasons. 
When employers say "you have not done business for months; this is your last chance; you can never find clients", he responds saying "I will not make drawings to gain clients; I gain clients to make drawings", which emphasizes that in fact process is as important as result (Figure 12).

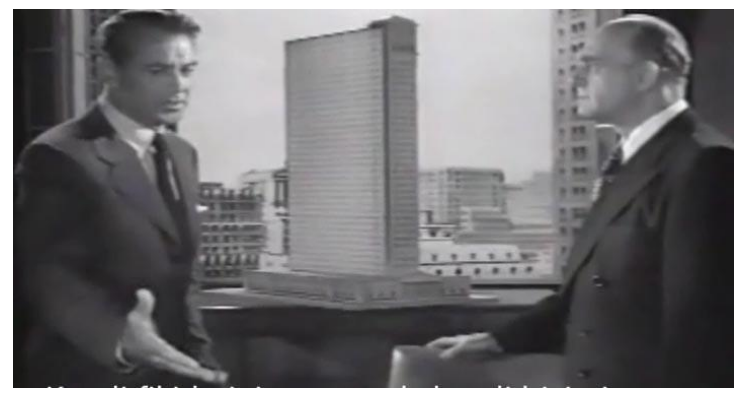

Figure 12. The architect's struggle with the employer for whom he works (Fountainhead)

However, Peter Keating, in the same film again, is a character who has voluntarily submitted himself to the taste of the employer, copies historical buildings, and has not concerns about good design; instead, he is an architect who produces works for with fame and wealth in mind. Keating argues that one cannot survive without making concessions, one has to make drawings compatible with people's wishes and that one can attain a good position in one's career if one gives people what they want. While Roak fights against economic problems, the society and the courts, Keating is billowing in wealth, fame and praise.

In the Lake House, Kate Forster consults and asks Wyler Architecture Office to restore the house she would like to live in. From the dialogues in those scenes, one gets the opinion that the architect is someone who makes old items usable again for people, gives life to old things, makes people happy and puts on paper others' dreams then implements them. In the film The Lake House, architect presents his ideas to his employer in the form of drawings but unlike Howard, considers it a virtue to listen to clients' ideas and demands and make the necessary 
alterations in accordance with their demands. The film The Lake House lays before eyes various aspects of architecture, and by ending the final scene in a frame where the House and two happy people going to it, emphasizes that architecture is an endeavor aimed at bringing happiness to people (Figure 13).

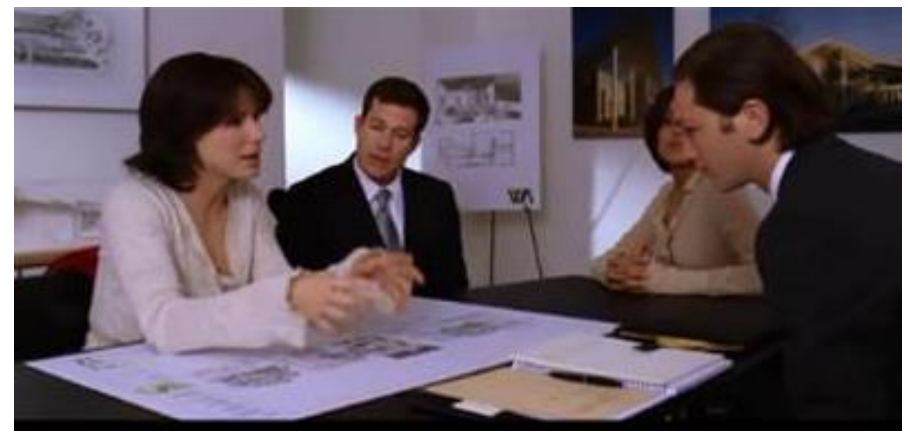

Figure13. The reconciliatory attitude that the architect assumes towards the employer for whom the design is made (The Lake House)

When the student of architecture in Inception, Ariadne, is offered an unusual job of "designing a dream", although the employer first puts her to a strange "test of labyrinth design" and she sees that it is a dangerous thing to surfing one's subconscious and that the purpose of the job offered is illegal, she cannot refuse the experience defined as "pure creativity". When, in the film Inception, a group of people who enters people's dreams and steals their ideas/infuses ideas in them holds a meeting with Ariadne, a student of architecture, to help them, she asks them "what has this got to do with architecture?", to which they respond with a counter question "someone has to design dreams, don't they?", which demonstrates the deep-rooted function of the architect and architecture. The architect character in the film is a utopian one who makes analyses, changes, brings into life or destroys. 
The fact that architects cannot refuse the opportunity of making designs in a world where physical rules do not apply is an example of the fact that architects sometimes accepts a job for the sake of process, not for the result (Figure 14).
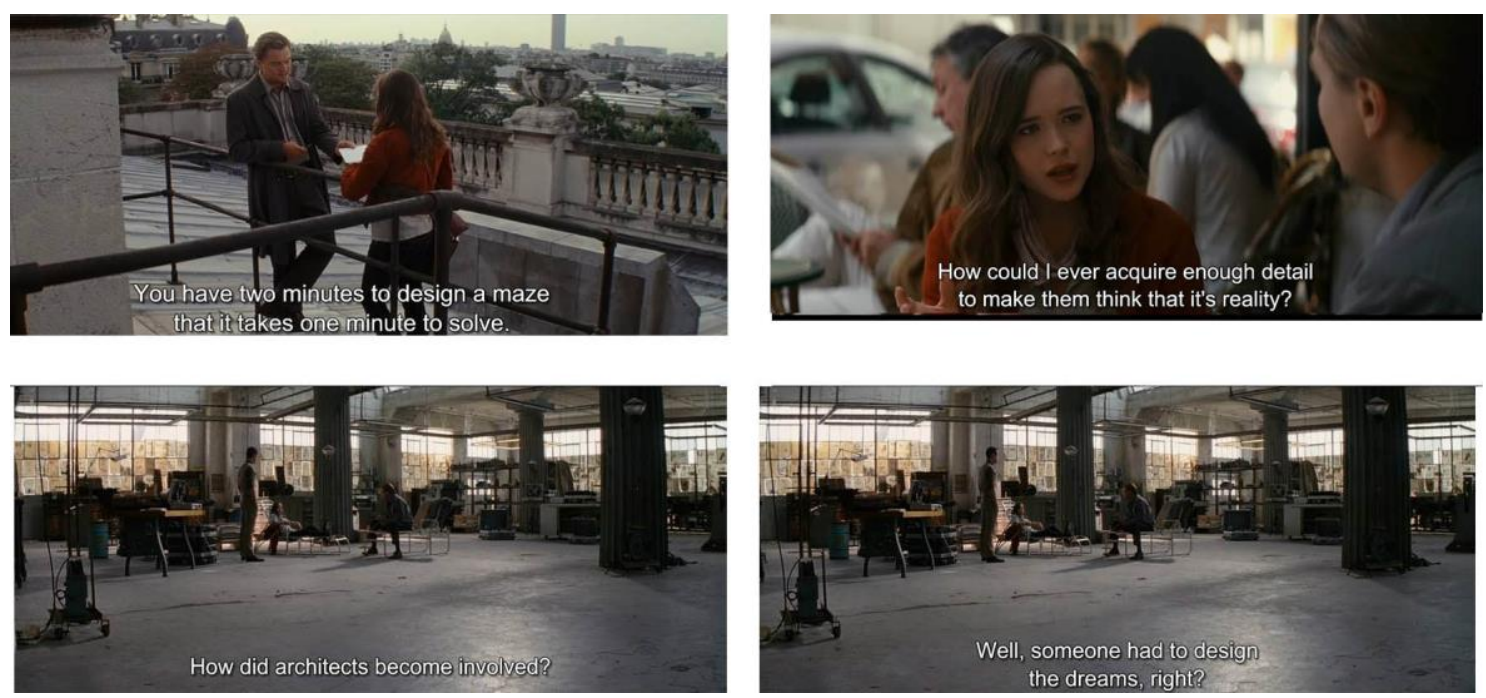

Figure 14. Various ways in which architects get jobs (Inception)

\subsection{The Relationship between the Architect and the Design}

It is observed that architects tend to identify their jobs with their profession. It is not possible to consider the products made through creative work separately from their designers. Howard Roak in the film The Fountainhead is a typical example of this. Roak perceives his designs as part of his identity. In his defense against the public prosecution opened as he dynamited the project he himself had designed, he said "My ideas are my property. They have been wrested from me by force in violation of a contract. They thought that my work might belong to others as they wished. I designed Cortlandt, I made it possible and I pulled it down...", which clearly expresses the relationship between the architect and the design. While 
they are making their designs, they bear, perhaps without being aware of it, on the visual, mental, emotional, tactile and intellectual experiences they have gained throughout their lives. Indeed, in the film The Fountainhead, Dominique finds it unbearable to live in the house which the architect she is in love has designed while she is married to another man because she has identified Howard's design with his identity and perceived the design as part of the architect.

In the film The Lake House, Alex, who lives in the lake house, is the son of architect Simon Wyler, the designer of the house, and is himself an architect, describes the house as "a glass box from which you can see everything around but cannot touch. Beautiful but incomplete" and adds "it totally reflects my father". The lake house has been designed by architect Simon Wyler, but his son architect Alex has added his own style to it. The transparent house built on the lake is a sign that the architect does not even draw a line without a reason or move a stone again without a reason. It is emphasized that the reason why the tree right in the middle of the lake house is there is linked to the building of dreams and concepts. The dialogue in the film between Alex and Simon Wyler on the design of a museum needs to be dwelt on so that we can understand the issues the architect of the design concentrates on. From the conversations between the father and the son, who are at the same time two colleagues, one understands that it is the architects who, in pursuit of the most beautiful, the best and the ideal, imagine the light, the material, the space and the people, and hence make their designs accordingly. 
The architect character in the film Life as a House, George Monroe makes models in an architecture firm. After the shock he has got when he is dismissed from his job as computer modelings have replaced models, he learns that he has only numbered days to live.

He decides to realize the dream of building his own house, which he has postponed for twenty years, and thanks to the construction of this house that the pieces of his scattered life, including his son, who is grappling with the problems of adolescence, and his ex-wife, all come together. He will demolish, with his very hands, the old house, which he hates due to all the memories of his youth plagued by his father's bad treatment of him, and again with his own hands he will build the house of his dreams. The house comes to represent almost a reconstruction of dreams once ruined. Even when he is in the grip of death, George Monroe defines, as an architect, this house to his son as something he has himself designed and something he will leave behind proudly after his death. George defines himself via this house, which he has designed and built, and the film ends with the voice of George coming from the other world commenting on the house built on the edge of a cliff; 'I have always dreamed myself as a house...I have always become the thing that lives in it. I did not need to be big. I did not even need to be beautiful. It only needed to be mine. I became what I needed to become. I built myself a life... I listen on a hill. It is almost complete. If you were a house, Sam, you would like to be built here. On a hill overlooking the sea, listening...' George wants to "rebuild his life" as an architect. In the film "A New Life", in which the act of building in architecture is identified with the concept of uniting, the architect serves as a keystone (Figure 15). 


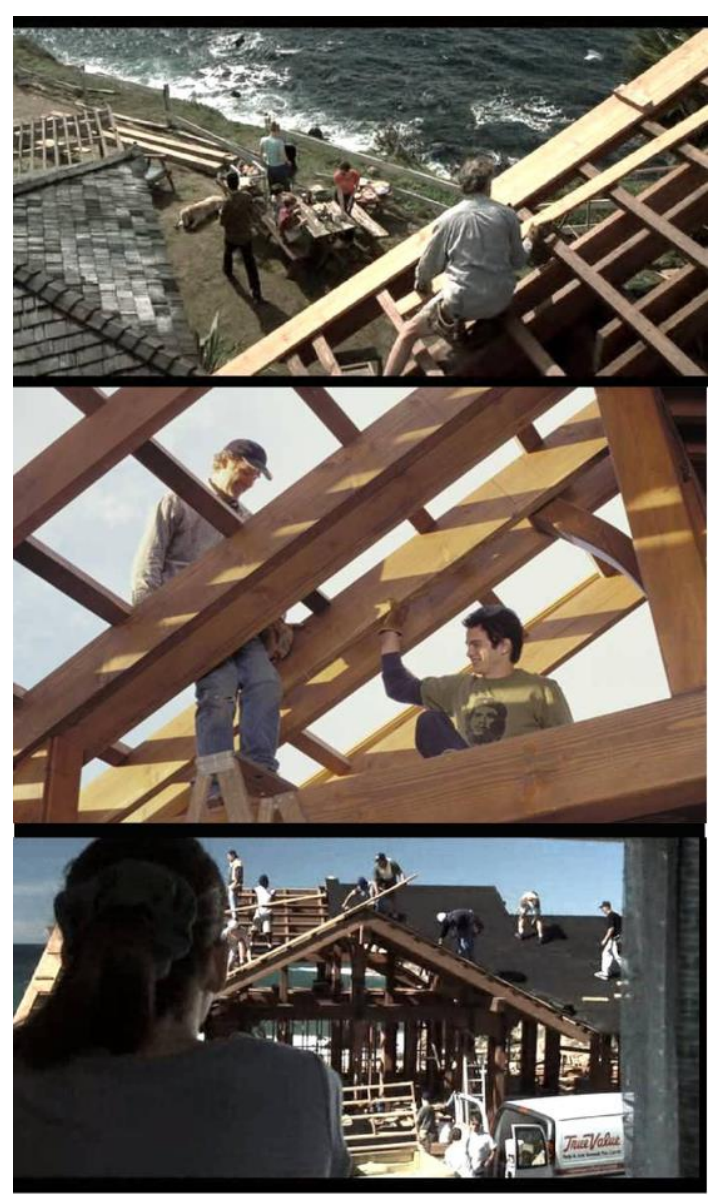

Figure 15. The architect builds human life as well as a building (Life as a House)

In the film 500 Days of Summer, the architect is depicted as having an ordinary life. He experiences failure, seeks ways of fighting, and makes psychological analyses and syntheses on an architectural task in which he prepares the skyline of the city (Figure 16). 

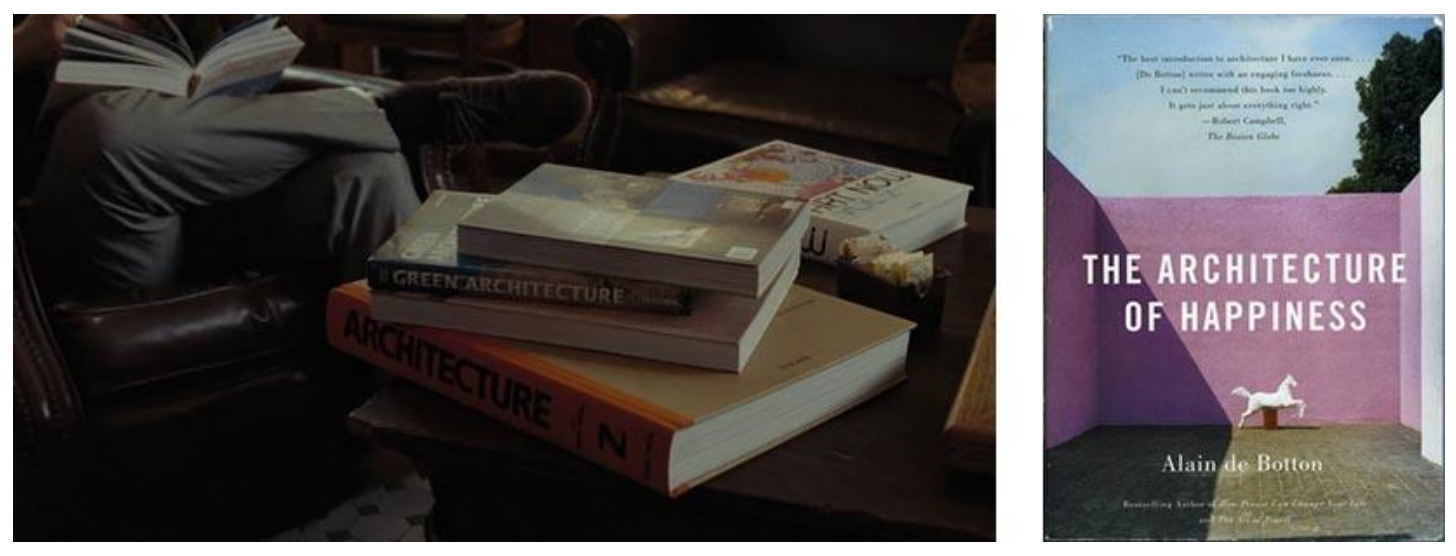

Figure 16. The profession of architecture is seen as a way of resurrecting one's self

In the film Truman Show, Christof, who is the director of the film and at the same time an architect, designs not only the houses, roads, and buildings on the island, which he has designed as a film set, but also life. All the houses, streets, neighborhoods, relationships, families, and neighbors are part of a TV set. The story takes place in an urban or suburban utopia. When viewed in terms of planning or architecture, the question of to what extent we can exert control over our environment or the place where we live is repeatedly brought up throughout the film. The places and the relationships in Truman's life are work of a designer. Architect Christof believes that he has provided a good life to Truman, who he has confined to an island for the sake of show business. The person who has turned Truman into a show and his God talk -the intellectual and spatial architect of the show - and this persuasive sentence in the final scene is like a confession of the fact that the design in the dreams has been fulfilled. "Outside, there is no more truth than in this world, which I have created for you. The same lies, the same hypocrisy..." The director looks at Truman, who goes on his way struggling with the artificial storm, having overpowered his fears, in grief and asks; "Truman, where are you heading for?" "To the truth, of course to the truth, to the real world, which is open to all kinds of surprises and where one is the master of their destiny free from all." Determined to go to the 
real world of which he will not only be an actor but also the director, Truman gives a final salute to the viewers in front of the EXIT door as if out of spite to the director and manages to go through the (Figure 17).

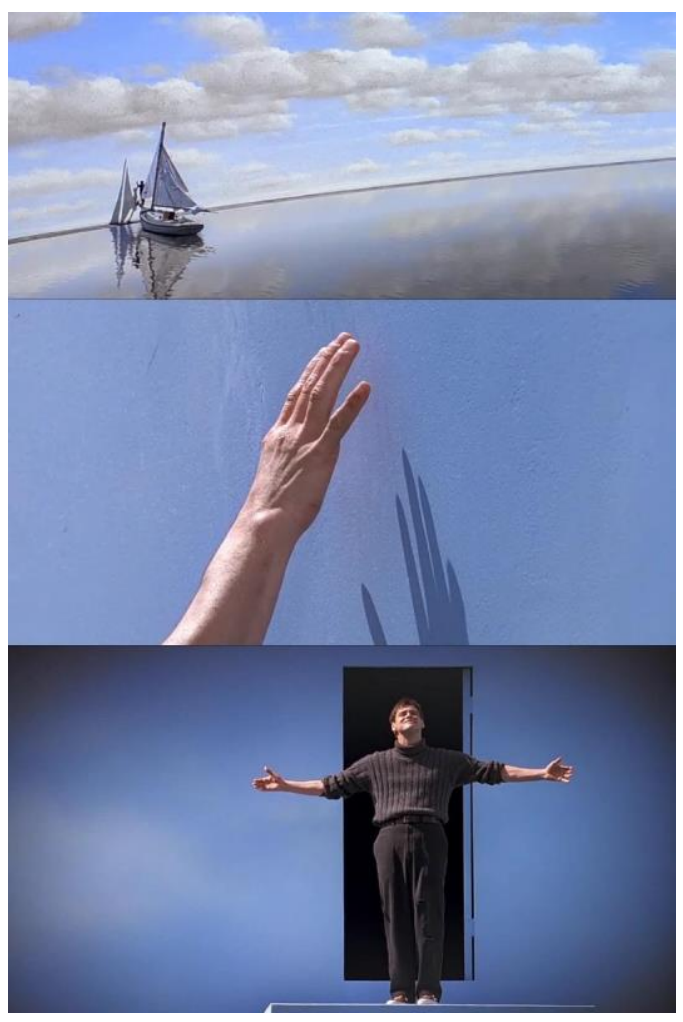

Figure 17. Architect and architecture are so presented as to touch upon the realities of life

\section{CONCLUSION}

This study aims to revise the questions of; What does an architect do? How does an architect work? What are the tools that an architect uses? How does an architect create their works? What is the mental map of an architect like? In short, who is an architect? through the cinema. The following conclusions have been drawn, via a total of eleven different characters of 
architects in seven films, about architects and architects' job from the cinematographic level to professional practice and architectural life:

\section{Architects' methods of working and tools}

Desk job-in the office

- Sketch

-The image of an architect making sketches at a white, lighted, wide and flat table is common.

-The sketch is a way of thinking and communicating for an architect.

-Architects make sketches on every surface where they can express themselves in the course of daily life

-By drawing the skyline of a city, architects express their visual ideas via sketches.

-Thinking via sketches, creating sketches and communicating with sketches is a way of existence for an architect

- Drawing

-An architect produces presentations of sketches accompanied by plans, cross-sections and frontal technical drawings

- An architect stands opposite the space, sees it, feels it and speaks through his drawings.

\section{- Model}

-The model is an important expressive technique for an architect that provides perceptual ease

-For architects, architectural models are sometimes a way of getting rid of worldy and ordinary burdens imposed on them by life. 
-For architects, models can be a source of passion created with patience.

-Three-dimensional digital models can be more effective than hand-made models

-Telling the employer about alterations to a design on models is an effective method that architects use

-Architects use models by breaking, adding and subtracting in three-dimensional thinking.

\section{- Construction Site}

-Architects offer solutions of design at the time and place of application

-Architects, when necessary, demonstrate their knowledge through use of tools during a project application at a construction site

-Architects perform the job of work schedule, coordination, selection of materials and distribution of tasks thereby enabling smooth flow of work.

\section{- City}

-Architects like walking in the streets of a city, watch the buildings they like, focus on their details and making observations on buildings

-Architects may stand on the roof of a building all day long, and watch buildings in the ever-changing sun-light.

-Architects hang around in the streets of a city on a day when the light is crystal clear and "touch" the details of buildings

- Architectural observations of cities where architects live and thus feeding visual memory is a working method often used by architects. 


\section{- Other Methods of Working}

Apart from the partially traditionalized work of architects involving sketches, drawings, models, and desk job as well as their lives at construction sites, we also see contemporary and highly predictive architectural methods and conditions of work in films. Architects possess the skills to design a mental world and even spaces of dreams.

-Architectural characters can be film producers and directors.

-Architects design not only buildings and the shape of the island but also lives of people.

-Architects are writers as well as directors.

-Architects are people who write books and convey their works, sketches, ideas and sources of inspiration to future generations.

\section{The relationships of architects with employers}

It is observed that architects establish relationships with employers in four different ways;

-Architects may display a contentious relationship with employers for whom they work; they may avoid making concessions to clients even at the expense of losing a job saying, "I do not make drawings to gain customers; I gain customers to make drawings", which shows that they take the process as seriously as they do the result.

-Another architect character is one who has voluntarily submitted himself to the wishes of the employer. He copies historical buildings, and performs his job with a focus on fame and wealth rather than design. 
-Another attitude taken by architects involves a conciliatory relationship they establish with employers. Architects present his ideas to the employer in the form of drawings, listen to the customers' ideas and demands and consider it a virtue to make alterations in accordance with their wishes. It is emphasized that architects work to ensure people's happiness.

-Some architects can accept jobs defined sometimes as "pure creativity" for the sake of the process rather than the result.

\section{Architects' relationships with their designs}

-Architects perceive their designs as part of their self. It seems that architects tend to identify their job with their identity. It is not possible to consider products manufactured as a result of a creative process separately from their designers. While they are making their designs, architects, perhaps without being aware of it, make use of their visual, mental, emotional, tactile and intellectual experiences.

-In the films, as a creative activity, architecture is shown to be a source of life and a cure against love pains and depression. Architecture is seen as a way of recreating one's self.

-The fact that an architect has dynamited his own building as they have not remained faithful to his design is associated with respect for one's design and the self.

-Architects and architecture are presented in such a way as to touch upon the realities of life. 


\section{BIBLIOGRAPHY}

Gençosmanoğlu Beşgen, A. 2012. CINEJ Cinema Journal, To Find Is To Choose, To Choose Is To Create: Culture(s) in Cinematic and Architectural Space(s) Stoker's Dracula (1992), Volume 1.2 (2012), DOI 10.5195/cinej.2012.15.

Hasol, D. 2005. Ansiklopedik Mimarlık Sözlüğü, Yapı Endüstri Merkezi Yayınları, İstanbul.

Vitruvius, P., 1993, Mimarlık Üzerine On Kitap, ç. M.H. Moran, Şevki Vanlı Yayınları.

Tanyeli, U., 2001. Sinema ve Mimarlık: Temsiliyet Nesnenin Temsili Sanatın Sanallıkla İfadesi", Journal of Arredamento Mimarlık, 11:66.

Türk Dil Kurumu Sözlüğü. 1969. Ankara.

http://www.filmreference.com/Writers-and-Production-Artists-Vi-Win/Winkler-Irwin.html\#b http://en.wikipedia.org/wiki/Irwin_Winkler http://www.intersinema.com/irwin-winkler-filmleri/ http://www.beyazperde.com/filmler/film-28398/ 